\title{
Antibody Survey of Bovine Viral Diarrhea in Bali Cattle
}

\author{
Putu Henrywaesa Sudipa ${ }^{1}$, Luh Made Sudimartini ${ }^{2}$, I Wayan Wirata ${ }^{3}$ \\ ${ }^{1}$ Veterinary Bacteriology and Mycology Laboratory, Veterinary Pathobiological Department, \\ Faculty of Veterinary Medicine Udayana University, Bali, Indonesia. \\ Email: henrywaesa@unud.ac.id \\ ${ }^{2}$ Veterinary Physiology, Pharmacology and Pharmacy Laboratory, Veterinary Clinical \\ Department, Faculty of Veterinary Medicine Udayana University, Bali, Indonesia. \\ Email: md_sudimartini@unud.ac.id \\ ${ }^{3}$ Veterinary Surgery Laboratory, Veterinary Clinical Department, Faculty of Veterinary \\ Medicine Udayana University, Bali, Indonesia. \\ Email: iwynwirata_dvm@unud.ac.id \\ Corresponding Author: henrywaesa@unud.ac.id
}

\begin{abstract}
Bovine Viral Diarrhea (BVD) or malignant diarrhea in cattle is one of the animal diseases that causes economic losses in the cattle industry worldwide. The biggest economic loss due to infection by Bovine Viral Diarrhea is related to reproductive and calf disorders that continue to transmit the virus to other cattle. This study aims to determine the presence of Bovine Viral Diarrhea antibodies in Bali cattle. The sample uses Bali cattle's blood from 30 cows that are accommodated in 2 tubes that contain anti-coagulant and which do not contain anti-coagulant. After being processed to get serum, plasma and buffy coat cells, then the samples were examined using the ELISA method and presented descriptively. The results showed that there were positive suspects in Sobangan village, Badung with 8 out of 15 samples (53\%) and positive suspects in the village of Payangan, Gianyar with 3 out of 15 samples (20\%). Positive results are influenced by biosecurity of each type of sample farm, in Sobangan village is a large farm so biosecurity is difficult to implement and the spread of disease is faster than in Payangan village that have small farm type.
\end{abstract}

Keywords: Bali Cattle, Bovine Viral Diarrhea, ELISA.

\section{INTRODUCTION}

Bovine Viral diarrhea (BVD) is an infectious disease in cattle caused by a virus. This virus is easily transmitted among cows and has spread widely throughout the world. BVD viruses can be transmitted horizontally or vertically [16]. BVD has been endemic in Indonesia with reactor prevalence rates varying and, in some areas, quite high. BVD disease in Indonesia first occurred in 1988 and attacked Balinese, Brahman, Brahman Cross, Peranakan Ongole (PO) breeds, male and female of all ages. BVD virus has a high morbidity but mortality is very low. In 2006 there were reported cases of BVD of 1190 cases in Indonesia.

The greatest economic loss due to infection by Bovine Viral Diarrhea Virus 
(BVDV) is related to reproductive disorders [4]. Reproductive disorders due to infection by BVDV include failure of conception, early embryonic death, abortion, congenital malformations, weak birth calf, and persistent virus infection. Persistent BVDV infection is the most detrimental consequence because it is immunotolerant and is a factory producing BVDV that transmits the virus quickly and continuously throughout its life through direct contact with sensitive and unvaccinated cows [7]. Therefore, it is necessary to conduct research to detect BVD antibodies in Bali cattle so that initial data can be obtained and preventive measures taken to overcome BVD infection.

\section{MATERIALS AND METHODS}

This research was conducted from May 2019, samples were taken in the villages of Sobangan, Badung and Payangan Village, Gianyar, then the samples obtained were examined at the Veterinary Immunology laboratory of the Faculty of Veterinary Medicine, Udayana University. The sample uses cow's blood from 30 cows that are accommodated in 2 tubes that contain anti-coagulant and which do not contain anti-coagulant. After getting serum, plasma and buffy coat cells, then the sample is examined using the ELISA method. Then tabulate the data obtained to see if there is a positive ELISA result containing BVD antibodies. Then the data obtained are presented descriptively.

\section{RESULT AND DISCUSSION}

Table 1. Elisa Test Result of Antibodi Bovine Viral DiarrheaIn Bali Cattle at Sobangan Village, Badung.

\begin{tabular}{cc}
\hline Sample Code & Result \\
\hline A1 & 0.865 \\
A2 & $1.12^{*}$ \\
A3 & $1.133^{*}$ \\
A4 & $1.296^{*}$ \\
A5 & $1.393^{*}$ \\
A6 & $1.328^{*}$ \\
A7 & $1.149^{*}$ \\
A8 & $1.217^{*}$ \\
A9 & 0.99 \\
A10 & 0.882 \\
A11 & 0.737 \\
A12 & 0.896 \\
A13 & 0.939 \\
A14 & $1.029^{*}$ \\
A15 & 0.763 \\
\hline
\end{tabular}

Information: $*=$ Positive 
Tabel 2. Elisa Test Result of Antibodi Bovine Viral DiarrheaIn Bali Cattle at Payangan Village, Gianyar.

\begin{tabular}{cc}
\hline Sample Code & Result \\
\hline G1 & 0.946 \\
G2 & $1.091^{*}$ \\
G3 & 0.894 \\
G4 & 0.7 \\
G5 & $1.337^{*}$ \\
G6 & 0.989 \\
G7 & 0.73 \\
G8 & 0.985 \\
G9 & 0.614 \\
G10 & 0.615 \\
G11 & 0.725 \\
G12 & 0.716 \\
G13 & 0.683 \\
G14 & 0.724 \\
G15 & $1.045^{*}$ \\
\hline
\end{tabular}

Information: $*$ Positive

From the results of examination of Bali cattle samples for BVD antibodies by ELISA test in Sobangan Village, Badung as in Table 4.1 the results obtained are 8 out of 15 samples (53\%) showing positive results with BVD antibodies, while the results of checking BVD antibodies in cattle Bali with ELISA test in Payangan Village, Gianyar as shown in Table 4.2 shows that 3 of the 15 Bali cattle samples (20\%) tested positive for having BVD antibodies.

ELISA antigen test can be used to determine (screening) early in looking for animals that have persistent infections as the main infectious animals in the spread of BVD disease in farm [1]. This test is the latest breakthrough in detecting the early presence of persistent infection animals that have been proven to be accurate before a polymerase chain reaction ( $\mathrm{PCR}$ ) test is done, but it will be more efficient when screening early because this test is fast and accurate [16]. The above research results can only be said to be suspect positive for BVD because to further ensure the virus is BVD it is necessary to carry out further tests such as Polymerase Chain Reaction (PCR), RT-PCR or other molecular tests.

Antibody serology test results obtained from positive studies, but in negative antigen serological tests caused by several things. Antibodies detected against the BVD virus in cattle breeding areas can occur due to natural infection during maintenance / fattening in the cage [7]. The spread of the disease occurs directly through contact with infected animals, especially those with persistent infections, while indirectly through food contaminated with urine, feces, oronasal secretions or from 
fetal fluid abortion fetus [14]. Transmission can be carried between farms by officers who are in direct contact with infected cows. Infection occurs very quickly among sensitive cows by direct contact, but the clinical signs that are seen are not clear accompanied by an irregular incubation period of the disease [11]. High positive suspect results that occur in the village of Sobangan, Badung is likely to occur due to the type of the farm that has a large number of broodstock and calf cattle, which is approximately 200 Bali cattle in one place, resulting in rapid virus transmission, in addition to the application of biosecurity strict conditions are rather difficult to do with a large number of Bali cattle, such as in the village of Sobangan, Badung. This is different from the sample taken in Payangan Village, Gianyar where although it is still traditionally maintained by the family of farmers behind the house, the number of cows is not as much as in the village of Sobangan, Badung, so the positive suspect results are lower. Each breeder's family only has a maximum of 2 bali cattle which are used as samples for this study. This has an effect on the spread of the disease which becomes localized in one cage in the breeder's family, the distance of the cage of each breeder's family is quite far and the breeder's family is more alert to supervise if the disease occurs in their domestic Bali cattle.

Adult Balinese cattle whose blood samples are taken on average do not show clinical symptoms of BVD, this is likely due to differences in the types of BVD where according to [8] BVD in Indonesia there are 2 types namely BVD- 1 and BVDV-2, when seen from the occurrence of BVDV-2 more virulent than BVD-1 and both cannot be compared in terms of anatomic pathology and histopathology and definitive diagnosis requires virological and molecular biology studies [17]. But not all BVDV-2 isolates cause severe clinical symptoms. In nature, avirulent BVDV-2 is more common than virulent BVDV-2 [21]. Usually infection by postnatal BVD virus is non-clinical, with a biphasic temperature rise with leukopenia followed by a specific immune response that can be measured by a serum neutralization test. In addition, ELISA antibodies can detect the presence of persistent infection (PI) in fetuses born to mothers infected by BVD in old pregnancy (9 months gestation) [10]. However, if the adult Bali cows we sampled gave birth to a calf, it is not yet known whether the calf would later be a persistent infection (PI), so this research needs to be continued to detect this.

\section{CONCLUSION}

Positive suspect results that occurred in the village of Sobangan, Badung (53\%) are likely to occur due to the greater number of cows on the farm than the number of cows in the village of Payangan, Gianyar $(20 \%)$ where the number of cattle is smaller. So biosecurity that is applied in the village of Sobangan, Badung is more difficult to do and the spread of disease is faster than in the village of Payangan, Gianyar. Balinese cattle whose blood samples are taken on average do not show clinical symptoms of $\mathrm{BVD}$, this is likely due to differences in the type of BVD, but if giving birth calf is not yet known whether the calf will later as a persistent infection (PI) or not. 


\section{REFERENCE}

[1] Burgess GW. 1995. Teknologi ELISA dalam Diagnosis dan Penelitian. Artama, WT, penerjemah. Yogyakarta (ID): UGM Pr. Terjemahan dari: ELISA Technology in Diagnosis and Research.

[2] Brennan ML, Kemp R, Christley RM. 2008. Direct and indirect contacts between cattle farms in north-west England. Journal Veterinary Medical 84: 24-260.

[3] Brock KV. 2004. The many faces of bovine viral diarrhoea virus. Vet. Clin. North Am.: Food Anim. Pract. 20:1-3

[4] Darmadja, S.D.N.D. 1980. Setengah Abad Peternakan Sapi Tradisional dalam Ekosistem Pertanian di Bali. [Disertasi]. Bandung: Universitas Padjadjaran.

[5] Deregt D, Loewen KG. 1995. Bovine viral diarrhea virus: biotypes and disease. Can. Vet. J. 36:371-378

[6] Ellis JA. 1998. Lesions and distribution of viral antigen following an experimental infection of young seronegative calves with virulent bovine virus diarrhea virus type II. Can Journal Veterinary Res 62: 161-169.

[7] Fulton R. 2006. Bovine viral diarrhea virus persistent infections in beef breeding herds. Journal Medical Virology 23: 143-149.

[8] Fulton RW, Saliki JT, Confer AW, Burge LJ, D'offay JM, Helman RG, Bolin SR, Ridpath JF, Payton ME. 2000. Bovine viral diarrhea virus cytopathic and non cytopathic biotypes and type 1 and 2 genotypes in diagnostic laboratory accessions: clinical and necropsy samples from cattle. J. Vet. Diagn. Invest. 12: 33 38.

[9] Hardjosubroto, W. 1994. Aplikasi Pemuliabiakan Ternak di Lapangan. Jakarta: PT. Gramedia Widiasarana Indonesia.

[10] Jalali A, Torstenson M, Linberg A. (2007, Dec 13). Using a commersial indirect antibody detection ELISA to identify dams carrying PI foetuses- a complementary measure in bvdv control/eradication programmes. [online] Svanova Vet.Diagnostic.www.svanova.com.

[11] Kahrs RF. 2005. Viral Disease of Cattle Second Edition. Iowa (US): Iowa State University Pr.

[12] Kozasa T, Tajima M, Yasutomi I, Sano K, Ohashi K, Onuma M. 2005. Relationship of bovine viral diarrhea virus persistent infection to incidence of disease on dairy farms based on bulk tank milk test by RT-PCR. Vet Microbiol 106: 41-47.

[13] Lanyon SR, Hill FI, Reschels MP, Brownlie J. 2014. Bovine viral diarrhea pathogenesis and diagnosis. Journal Veterinary 199: 201-209.

[14] Middleton D. 2006. Vaccination of the cow in Western Canada. Journal Medical Virology 12: 25-34.

[15] Muhammad D, Rauf F, Yudiastyas DW. 2004. Situasi kasus bovine viral diare pada sapi di Sulawesi Selatan tahun. BulletinInformasi Kesehatan Hewan dan Kesehatan Masyarakat Veteriner 2: 12-16.

[16] Middleton D. 2006. Vaccination of the cow in Western Canada. Journal Medical Virology 12: 25-34..

[17] Odeon AC, Risatti G, Kaiser GG, Leunda MR, Odriozola E, Campero CM, Donis RO. 2003. Bovine viral diarrhea virus genomic associations in mucosal disease, enteritis and 
generalized dermatitis outbreaks in Argentina. Vet. Microb. 96: 133 144.

[18] [OIE] Office International des Epizooties. 2006. Indonesia report for 2005. Paris (FR): OIE.

[19] Putu IG, SitumorangP, LubisA, ChaniagoTD, TriwulaningsihE, SugiartiT, Mathius IW, SudaryantoB. 1998. Pengaruh pemberian pakan konsentrat tambahan selama dua bulan sebelum dan sesudah kelahiran terhadap performan produksi dan reproduksi sapi potong. Prosiding Seminar Nasional Peternakan dan Veteriner. Bogor, 1-2 Desember 1998.

[20] Primawidyawan A, Indrawati A, Lukman DW. 2016. Deteksi Penyakit Bovine Viral Diarrhea pada Sapi Potong Impor melalui Pelabuhan Tanjung Priok. Acta Veterinaria Indonesiana. Vol. 4, No. 1: 7-13.

[21] RidpathJF, Neill JD, Frey M, Landgraf JG. 2000. Phylogenetic, antigenic and clinical characterization of type-2 BVDV from North America. Vet. Microb. 77: $145-155$.
[22] Sudarisman. 2011. Bovine viral diarrhea pada sapi di Indonesia dan permasalahannya. Wartazoa 21: 1824. 2011.

[23] Sutan SM. 1989. Perbandingan Performans Reproduksi dan Produksi antara Sapi Brahman, Peranakan Ongole dan Bali di Daerah Transmigrasi Batumarta, Sumatra Selatan. [Disertasi]. Bogor: Institut Pertanian Bogor.

[24] Vilcek S, Paton DJ, Rowe LW, Anderson EC. 2001. Typing of Pestiviruses from eland in Zimbabwe. J. Wildl. Dis. 36:165168

[25] Weinstock D, Bhudevi B, Castro AE. 2001. Single-tube single-enzyme reverse transcriptase PCR assay for detection of bovine viral diarrhea virus in pooled bovine serum. J Clin Microbiol (39): 343-346.

[26] Wengler G, Bradley DW, Collett MS, Heinz FX, Schlesinger RW, Strauss JH. 1995. Family flaviridae, Dalam: Murphy FA. Fauquet CM. Bishop CM. (Ed.) Viral Taxonomy NewYorkSpringer-Verlag. Hlm. 415427. 